\title{
The wife as stranger in the family
}

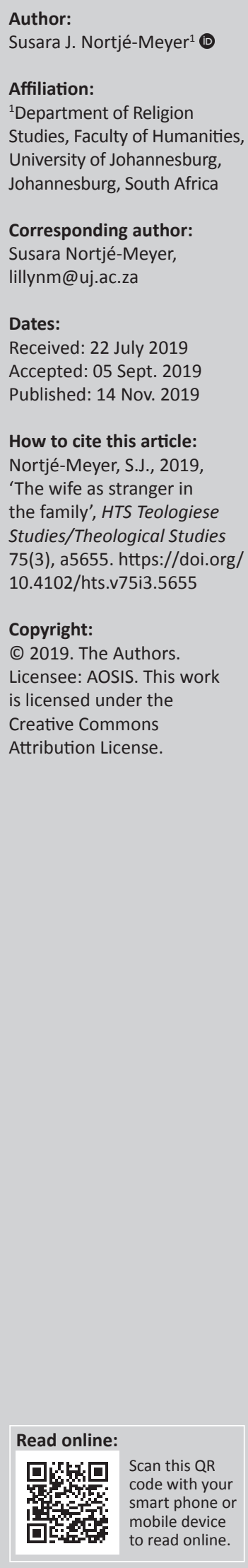

The phenomenon of the stranger reveals that spatial relations are, on the one hand, only the condition and, on the other hand, the symbol of human relations. This article discusses the specific form of interaction of the wife (woman) as a stranger in the context of the biblical family. The wife as a stranger is discussed here not in the sense often touched upon in the past, as a wanderer who comes today and goes tomorrow, but rather as a person who comes today and stays tomorrow. She is, so to speak, the potential wanderer: although she has not moved on, she has also not overcome the freedom of coming and going. She is fixed within a particular spatial group, or within a group whose boundaries are similar to spatial boundaries, but her position in this group is determined by the fact that she never belonged to it from the beginning. The unity of nearness and remoteness involved in every human relation is organised, in the phenomenon of the stranger, in a way which may be most briefly formulated by saying that in her relationships, distance means that she, who is close by, is also far away, and her strangeness means that she, who is far away, is also actually near. I examined the implications of knowing and identifying the wife as a stranger for feminist theory and its interpretation.

Keywords: wife; stranger; outsider; other; family; biblical family.

\section{Introduction}

The stranger appears throughout history as the trader who moves from place to place (the wanderer), therefore the trader was perceived as a stranger. It was not only the trader who was seen as a stranger, but the classical example is the history of European Jews, and current examples include the migration of people from Syria or Africa to Europe, and that of Mexicans to the USA. The position of the stranger stands out more sharply if she/he settles down in the place of her/his activity, instead of leaving it again. In many cases this is possible only if she/he could live by intermediate trade.

I examined the implications of knowing and identifying the wife as a stranger for feminist theory and its interpretation. The concept of feminist theory includes gender as culturally determined understandings, attitudes and belief systems about females and males; sex as the descriptive, biologically based variable used to distinguish females and males; and sex roles determining the patterns of culturally approved behaviours that are regarded as more desirable for either females or males (Gordon 2009). I argue that the strangeness of the wife extends to both her role as an outsider and to her continued bodily otherness. Power and prestige were located with men, so they formulated and determined the group norms and they had the power to name the stranger, and to narrate who belongs to 'us'.

In this article, the wife as a stranger is not discussed, in the sense, often touched upon in the literature, as the wanderer who comes today and goes tomorrow, but rather as the one who comes today and stays tomorrow.

She is, so to speak, the potential wanderer and not the wanderer. Although she does not move on, she has not quite overcome the freedom of coming and going, unless she runs off (cf. Jdg 19) or is sent away (Ezr 10:3). It is the despised wife forced into prostitution who becomes the wanderer. In antiquity, a woman who was not part of a family (group) had no other choice than to be sold as a slave or become a prostitute to make a living. There is therefore a limit to the analogy between the stranger and the wife.

In his discussion on identity and strangerhood, Marotta (2002:42) refers to Zygmunt Bauman's important themes of 'order' and 'ambivalence' in the construction of social world. According to Bauman (1997), the stranger symbolises the very ambivalence that is attempting to destroy the

Note: The collection entitled 'Eben Scheffler Festschrift', sub-edited by Jurie H. le Roux (University of Pretoria) and Christo Lombaard (University of South Africa). 
reasons for ordering constructed by the society (including the family). These disruptions lead to 'a societal establishment of a meta-order, thereby suppressing and excluding any individual or group that comes to symbolise disorder or ambivalence' (Marotta 2002:38). He articulates strangerhood in multiple ways, and 'different conceptions of identity underlie these multiple constructions' Bauman (1997:17). He conceptualises the stranger as the social or cultural 'other', and implicitly links the experience of strangeness to existential experience. A collective identity is constructed to establish difference and to protect the boundaries of the society or family. In the process, the construction of an 'us and them' demarcates the boundaries, and the stranger plays an important role in defining these boundaries. At the same time, the stranger as the cultural 'other' makes the boundaries porous, unstable and problematises them (Bauman 1991:55). Marotta (2002:42) says: '[ $t$ ]he stranger in this dimension epitomises those in-betweens, the insiders-outsiders ... who threaten the insider/native's identity, because social and cultural boundaries become uncertain'. This stranger can be called the hybrid stranger occupying in-between identities where she/he is 'neither just this/nor just that' (Dayal 1996:47), 'neither the One ... nor the other ... but something else besides' (Bhabha 2001:41). Hybrid identity reflects the internal and external processes of identity construction.

Bauman (1997) connects the external processes of the stranger's identity construction to those who are considered strangers by society, to those who disrupt the accepted 'society norms', and ultimately to those in a position of hybridity. If the strangers do not fit the internal processes of cognitive, moral or aesthetic mapping of the society, if their sheer presence makes obscure what ought to be transparent, confuses what ought to be a straightforward recipe (or norm) for action:

... [T] hen each society produces such strangers; whilst drawing its borders and charting its ... maps, it cannot but gestate people who conceal borderlines deemed crucial to its orderly and/or meaningful life. (Bauman 1997:34)

The question (especially in this article) is not how to get rid of the strangers and the strange but how to live with them daily and permanently (Bauman 1997:46).

Whatever realistic strategy of coping with the unknown that society has formulated to balance with the uncertainty and the confusion of living with the stranger, it must come from recognising the reality of the presence of the stranger (Bauman 1997:55). The stranger also has to reconcile the need for belonging to the society (family), for a permanence of home, suggesting that - for the hybrid identity - the stranger who does not belong, holds a painful loss of identity (Bauman 1997:136).

Ahmed (2000:50) uses anthropological knowledge to identify strangers as those who become our friends, but who (unlike the wife) do not inhabit the same space. We want to include them into our homes, get closer to them, rather than to expel them. The stranger becomes both familiar and strange and the community (family) marks out the boundary between familiar and strange. However, the understanding of the stranger-woman as wife allows her to enter the community (family) as a distinctive figure.

\section{The wife as stranger}

The new wife as stranger threatens the boundaries of the ordering process that imposes stability and predictability on the family. She is fixed within a particular spatial group, or within a group whose boundaries are similar to spatial boundaries. But her position in this group is essentially determined by the fact that she has not belonged to it from the beginning, that she imports qualities that do not and cannot stem from the group itself, qualities that have the potential to be rejected or disapproved of by the group. She brings these qualities from her own group (family) where she was prepared for a married family by her own family who instructed her on female behaviour, obedience, submissiveness and service (Dreyer 2005:734).

The wife is not the obvious stranger. She is not someone we do not recognise but someone whom we recognise as a stranger:

[S]omebody we know as not knowing, rather than somebody we simply do not know ... Strangers are not simply those who are not already known in a particular dwelling, but those who are, in their very proximity, already recognised as not belonging, as being out of place. (Ahmed 2000:49)

We recognise these strangers (such as the wife) as distant when they are close by (Simmel 1950:402-408), particularly when they are included into the family. The stranger comes to be seen as a figure when she has entered the space we call 'home'.

The reason for including the stranger-wife in the family space is her potential to produce offspring and specifically male offspring. Malina (1981:112) says that the '... intention in marriage is on offspring ... this being the sole valid motivating factor in sexual encounters'. The wife's ability to produce offspring could be seen as her intermediate trade, the product that allows her to stay in the family group.

However, the family boundary is still marked out between familiar and strange until she produces the product the group wants, namely a male offspring. If she cannot produce a male offspring, she threatens the boundaries of the ordering process that imposes stability and predictability on the family; she threatens the insider/ native's identity. Infertility was a reason for divorce, and the wife might face the consequences and be sent away (Instone-Brewer 2002:92-93). She might stay in the dwelling but the family (and community) sustains the marked-out boundaries and remains an insider-outsider (Marotta 2002:42). The translation of the strange into the familiar is when the stranger-wife, who has settled in, becomes the wife as outsider and eventually remains as 'the other' (Ahmed 2000:49). 


\section{The wife as outsider}

To be able to recognise the wife as outsider, in-group (and therefore the family as in-group) dynamics need to be considered. To understand how groups function, I apply the principles of social identity theory (SIT).

Social identity is that part of an individual's self-concept which derives from her/his knowledge of her/his membership of a social group (or groups - a person belongs to more than one group) together with the value and emotional significance attached to that membership (Tajfel 1981:255).

A group has to form, firstly, a group (or in-group) identity. According to McCutcheon (1999:61), systems or communities create a framework within which persons can be identified in terms of supposedly immanent characteristics. These characteristics are also called group norms, which can be defined as 'a scale of values that defines a range of acceptable (and unacceptable) attitudes and behaviours for members of a social unit' (Ukwuegbu 2008:541), and this is reflected in the group's speech, bloodline, faith, provenance and dress code.

Group norms have considerable significance for the group as well as individual members. In general, norms specify certain rules for how group members should behave. They bring order and predictability to the environment and help members to interpret the world and to determine appropriate behaviour. For the individual, they serve as frames of reference through which the world is interpreted, especially in new or ambiguous situations. For the group, they contribute to regulating the social existence and to coordinate group members' activities. It is by creating or formulating criteria or symbolic systems that insiders both define themselves and distinguish themselves from outsiders.

This identity sets them apart from other groups (called the out-groups) and leads to social comparisons with other groups. These comparisons result in significant forms of group behaviour. The members in the group favour one another whilst discriminating against members of out-groups (Esler 2000:158). It is the way people categorise one another and this is called labelling. The establishment of these criteria determine the group's boundaries of what it is to be a person in the group, and demarcates the group from other groups or outsiders.

To describe a group's identity, you have to evaluate a group positively through their in-group/out-group comparisons. Tajfel (1978:61-76) describes three classes (dimensions) of variables that should influence intergroup differentiation or identity in concrete social situations.

Firstly, the cognitive dimension refers to the simple recognition of belonging. Austin (1979:41) says of this that ' $\ldots$ individuals must have internalised their group membership as an aspect of their self-concept: they must be subjectively identified with the relevant in-group'.

Secondly, the evaluative dimension refers to the positive or negative connotations of belonging. This means that the social situation must be such as to allow for intergroup comparisons that enable the selection and evaluation of the relevant relational attributes' (Austin 1979:41). Central to this is group norms (Brown 1988:42-48).

Thirdly, the emotional dimension refers to the attitudes, such as love and hate, which members hold towards insiders and outsiders respectively. One extreme feature of social comparison, common in all groups, is the tendency of the ingroup to stereotype out-groups.

Stereotyping as another category constituting identity refers to the creation of simplified images of people that typically exaggerate intergroup differences and minimise intergroup similarities (Tajfel 1969:7-97).

This is why stereotyping contributes to the construction of the 'other'. The 'other' refers to a person who does not form part of the in-group and is made aware of her/his social role outside the in-group. This leads to stereotyping and how an individual fits into a particular group. Stereotyping contributes to the emergence of in-group favouritism. Individuals are likely to display favouritism when an ingroup is central to their self-definition.

For Pickering (2001:175), stereotyping imposes 'disciplinary power over people, the responsibility not to be deviant, not to cease patrolling between legitimacy and danger'. This effectively means that individuals are restricted in their behaviour in order not to cross the boundaries of the norms and values set by the group.

Personal identity is another category that needs to be explained. It refers to self-categories which define the individual as a unique person in terms of their individual differences from other (in-group) persons. Social identity refers to social categorisation of the self and others. These self-categories define an individual in terms of her/his shared similarities with members of certain social categories in contrast to other social categories (Ellemers, Spears \& Doosje 1999:13). This implies that when we perceive ourselves as 'we' and 'us' as opposed to ' $\mathrm{I}$ ' and 'me', it is an ordinary and normal experience in which the self is defined in terms of others who exist outside the individual person (but in the group) and therefore cannot be reduced to purely personal experience.

The strong bonds of affection, cooperation and sharing of available resources amongst the insiders (kin) draw the boundary between 'us' and 'them' (or 'us' and 'her'). Towards non-kin (outsiders) prevails an attitude of suspicion and competition. In-group bias can be defined as the tendency to favour the in-group over the out-group 
(Tajfel \& Turner 1979:33-47. Malina and Rohrbaugh (1992) describe the position of the new wife in the husband's family as follows:

As in all societies that exalt bonds between males and masculine rights, in the traditional Mediterranean world the new wife will not be integrated into her husband's family. She is like a stranger in the house, a sort of long-lost relative of unknown quality. (p. 29)

These societies were patriarchal, patrilocal, hierarchical, polygamic and endogamic in nature. The men remained in their family and near their place of birth. They formed a core of closely related male residents, and kinship ties were strengthened. Wives were drawn from neighbouring communities. Consequently, the women in the maledominated families were outsiders. Pickering (2001) formulates it as follows:

National cultures are discrete entities and equivalent units. All too often this has produced and perpetuated stereotypical forms of characterising 'us and them', the multiple Others who do not belong within the exclusive domain of 'our' own nation - or our own family. (p. 84)

Furthermore, because of the strong relationship between a mother and her son, the wife always had to take the second place, if not the third, after his sisters (Malina \& Rohrbaugh 1992:242, 272). In Leviticus 21:1-4, the rules for priests advise that a priest must lament the death of a close relative, such as his mother, father, son or daughter, brother or unmarried sister, but not people related to him by marriage, that is, his wife and her family. Malina and Rohrbaugh (1992) explain as follows:

A wife remained for most part on the periphery of her new husband's family. She would be perceived as a 'stranger', an outsider, by everyone in the house and would shed the stranger's role in some measure only when she became the mother of a son. The birth of a son assured her of security and status recognition in her husband's family. Moreover, a son would grow up to be his mother's ally and an advocate of her interests, not only against the father but against his own wife. In case of conflict in the household, daughters-in-law do not stand a chance. Thus, the wife's most important relationship in the family is to her son. (pp. 241-242)

Although the wife as a stranger has settled into the in-group family, being from an out-group family she is always considered an outsider.

\section{The wife as the other}

We have developed a wide variety of ways to frame people conceptually and emotionally as 'other' (Rock 2017:114). People project their suppressed hostility onto others, and demonisation of the other is a widespread phenomenon amongst people in all societies of all times (Hammond 1995:61). Most people from the margins of society have been framed as 'other' based on their race, ethnicity, gender, sexual identification, age, (in)abilities etc. This gives them a certain kind of identity, namely otherness (Vosloo 2004:71).
The cultural rules in a society determine the status system within that community. In antiquity the gender status system determined that men had a higher status than women and had access to and control of resources. Power and prestige were located with the men. Women had a lower status, and either had no access to resources or had limited control and no power (Dreyer 2005:733). Therefore, women had to rely on men (father, sons or husband) for resources and survival. Malina and Rohrbaugh (1992) say that:

$[W]$ ife-taking always results in the embedding of the female in the honor of her husband. She, in turn, symbolizes the shame of the new family, that is, its sensitivity to public opinion and concern for its own self-image. (p. 29)

\section{Countryman (1988) confirms that:}

[T] he wife was brought in from another family in order to preserve and sustain that of her husband through the bearing of children and the wise administration of the household. (p. 151)

The female gender, in general, is not 'one of us' but rather some fearsome 'other', because the dominant culture feels threatened by the presence of the other and needs to control it (Hammond 1995:67).

\section{Marriage arrangements and the wife as other}

Marriage regulations are related to the way in which society is organised. In biblical Israel there were three types of marriage strategies: the 'reconciliatory' (patriarchs), the 'aggressive' (kings) and the 'defensive' strategy (post-exilic second Temple period) (Malina 1993:159-161).

During the patriarch-immigrant period, marriages were endogamic, which meant that the spouse had to be from a person's own family as closely as possible without the danger of incest (Van Eck 2007:93), for example, Abraham married his half-sister Sarah (Gn 20:12) (Dreyer 2005:736). ${ }^{1}$

'Sexual hospitality' characterised the patriarch-immigrant period. Women (daughters and wives who had been married before) were 'presented' to others for the sake of the attainment of higher social status and economic advantage. ${ }^{2}$ During this period the wife was seen as part of the husband's properties and could be utilised for his own benefit.

During the period of Israel or the kings, fathers attempted to choose spouses for their daughters who were part of the

1 Nahor married his brother's daughter (Gn 11.29); Isaac married his father's brother's (his uncle's) son's (his cousin's) daughter (Gn 24:15); Esau married his father's brother's (his uncle's) daughter (his cousin) (Gn 28:9); Jacob married his mother's brother's (his uncle's) daughter (Gn 29:10); Amram, Moses' father, married his father's sister (his aunt) (Ex 6:20; Nm 26:57-59).

2.Abraham, for instance, offered Sarai to the Pharaoh for the sake of economic advantage (Gn 12:14-16). Lot offered his daughters, in the presence of his future sons-in-law, to the men of Sodom for the sake of the honour of his guests (Gn 19:69). The eldest and the youngest daughters of Lot's children (according to legend the 9). The eldest and the youngest daughters of Lot's children (according to legend the ancestors of, respectively, the Moabites and Ammonites) were sired by Lot himself (Gn 19:31-38). Abraham offered Sarai, his father's daughter, in other words, his half-sister, to whom he was married (Gn 20:12), to king Abimelech of Gerar for the sake of privilege in a new country (Gn 20:1-18). Jacob was prepared to overlook the rape of Dinah, his daughter with Leah, by Shechem, although Dinah's brothers, Simeon and Levi, took revenge (Gn 34:30-31; 49:5-7). On the other hand, Reuben dishonoured his father Jacob (Israel) by committing incest with Bilhah, Jacob's slave wife (Gn 35:21-22; 49:3-4). 
'family of orientation', in order to keep their daughters in the family (Malina 1981:107). The collective family honour was strengthened in this way, and the family did not lose its daughters. According to patrilocal custom, the sons, on the other hand, were encouraged to marry women who were not related to the family. In this way the family could be strengthened by introducing new members from the outside. In this case, the chance was higher for a daughter to give birth to a child with disabilities because of the close family relationship with her husband than for the sons whose wives were from outside the family boundaries. During this period, 'sexual hospitality' was prohibited (Dt 24:4). Married women as well as unmarried daughters belonged to the domain of the men in the family (Dreyer 2005:738). This type of marriage reinforces the wife's role as outsider and 'other' in the husband's family.

During the post-exilic second Temple period, marriage procedures were determined by cultic purity regulations (Dreyer 2005:738). ${ }^{3}$ Only marriages within the 'house of Israel', were permitted (Malina 1996:50). Through marriage the 'holy seed', that is, the physical 'children of Abraham', could continue (Malina 1993:137-138). The practices of circumcision and admission to the Temple as the place of God's presence were related to this view. Marriage reform regulations (Ezr 9-10) were meant to achieve the dissolution of undesirable 'mixed marriages' (Blenkinsopp 1991:457). Ezra $(10: 3,11 b)$ suggested that the Israelites make a covenant before God that they would send away all the foreign wives and their children. It is not mentioned that any foreign men were sent away. This action by Ezra the priest further reinforced the notion of the wife as stranger and outsider.

Ancient Israel's policies were determined by the purity ideology of the Jerusalem Temple cult - an ideology that marked Israelite society as patriarchal, exclusivist and hierarchical (Dreyer 2005:735). Marriage arrangements, including sexuality, were linked to the Temple cult codes of holiness and its 'classification' of people. This meant that 'holiness' was understood very specifically as 'separation'. Boundaries were drawn between Israelites and non-Israelites, between men and women. The household was seen as a replica of the Temple and its codes. Regulations concerning sexuality, and dietary and purity prescriptions, separated women from the rest of the household and limited them to the women's quarters (Neusner 1979:47).

\section{A woman's body as the other}

A woman's and a man's body is not only a flesh and blood entity, but is actually created by the society it lives in. In antiquity a man's body was the norm. Everything that did not match a particular male body was defective and dysfunctional.

3.For example, a priest was forbidden to marry a woman who had already "belonged to a man', such as a widow, a divorcee or a woman who had been raped. Those born eunuchs, those with deformed genitals and hermaphrodites could not marry at all, because they could not contribute to the continuation of the 'holy seed', the 'children of Abraham'.
The woman's body had an inferior position in the hierarchy of bodies. Women were stereotyped as passive and discreet, whilst men were stereotyped as active, energetic and passionate. Women were 'from birth the "other" gender and formed a bodily out-group in the male-dominated family and society' (Nortjé-Meyer \& Vrey 2016:60).

A woman's body is reduced to a permanent condition of dysfunctionality. The man is manager, initiator and doer; the woman is the receiver. Because of her passivity, she is seen as inherently weak. Therefore, she cannot control herself but has to be permanently controlled by men, and is perceived as naturally belonging to the household where she can be watched and controlled, especially sexually controlled. Even the way a woman is dressed, by covering her body, should reflect her inferiority, her inability to control herself, and her subordination to her husband and the men in the household. Again, the woman symbolises continuity of the regulatory body (she inferior, he superior) and the stability of the household controlled by men (Nortjé-Meyer 2008:103).

The metaphor of wife as the bride of Christ in Ephesians 5:27 demonstrates wife as the stereotypical 'other'. An important issue to be considered when defining a woman's bodily identity and to demarcate women's bodies in the Christian community is holy or holy ones (Eph 5:27). The author of Ephesians (in Eph 1:4) explains 'holy' as being without blemish. 'Without blemish' refers to the bodily flawlessness of the high priest and the animal offerings of the religious cult in ancient Israel (cf. Ex 29:1). In Ephesians 5:23 the author uses the metaphor of the body to indicate the relationship of Christ with the church. However, the wife's body must be cleansed and washed because of her impurity after birth giving and monthly periods, to be without stain or wrinkle or any other blemish, in other words, to be holy (Eph 5:27). This was not required of any men as members of the faith community, but fits perfectly the public order of women's identification and bodily demarcation. The process of becoming holy for the woman's body seems to involve a purification process because she's impure - the 'other' body and the gender that needs to be separated and controlled. This is only applicable to the wife because she is an imperfect and inferior body. Her 'inferior body is compared with the "perfect" body of the male and the male with Christ, not as a body but as the head' (Nortjé-Meyer 2003:184-187).

Although the wife as stranger, outsider and other is applicable to women universally at all times, the best biblical example to demonstrate the wife as stranger, outsider and other is the story of the Levi's concubine (Jdg 19) and her journey of abuse and rejection by her husband from whom she fled from Ephraim to Bethlehem; her father who let her leave with the abusive husband because she does not belong to him and her family of birth anymore; the host who pushes her out of the house because she does not belong to his household and his honour has to be secured by protecting the male guest; and the mob from the town who raped her 'body' all night and 
left her to die on the doorstep outside the house. The pivotal moment to reveal the wife as stranger, outsider and other is when the Levite cuts up her body and distributes her body parts into all the areas of Israel (Jdg 19:29). She belongs nowhere, neither in life nor in death.

\section{Conclusion}

The wife as stranger in the family has been discussed, not as the wanderer who comes today and goes tomorrow, but rather as the person who comes today and stays tomorrow. Although she has not moved on, she has not achieved the autonomy of being essentially part of the husband's family. In most cases, the wife as stranger 'is a contradiction: she transcends categories and is always excluded' (Marusek 2018:78). She is fixed within a particular spatial group, or within a group whose boundaries are similar to spatial boundaries, but her position in this group (the family) is determined by the fact that she did not originally belong to it; she imports qualities into it, such as childbearing, which do not and cannot stem from the group itself.

Although the wife as stranger has settled into the in-group, being from an out-group, she is still considered an outsider, an in-between, the insider-outsider. She is in a position of hybridity that reflects the internal and external processes of identity construction. The family boundary is still marked out between familiar and strange until she produces the product the group wants, namely a male offspring.

However, it is her bodily ability to produce offspring that defines her as the 'other' grounded on the classification of people according to the purity codes. The process of becoming pure for the woman's body involves a purification process that is repeated monthly. Therefore, she remains an imperfect and inferior body, from birth the 'other' gender, and forms a bodily out-group in the men-dominated family and society.

I hope that the construction of the identity of wife as stranger, outsider and the 'other' would be confined to antiquity, but two examples demonstrate alarming contemporary occurrences of the wife (woman) as the eternal stranger, outsider and other.

The first is a television advertisement broadcast in South Africa, promoting an insurance company, called the 'Motherin-Law Advert'. A seemingly newlywed couple sit for dinner, and the husband says to his wife that she should try his mother's recipe because it's much better than the food his wife has prepared. Later he tells her that his mother's kitchen was also cleaner. The wife takes offense and leaves the room. ${ }^{4}$

The second has appeared recently as a newspaper insert by a medical practitioner, Dr Heinz Mödler (2018:21). He reports that in the western region of Nepal, when a woman menstruates she is forbidden to enter the house. She has to stay outside in a small cabin for the duration of her periods. She still has to work in the fields but not in the house. Her own children are not allowed to touch her, and she is not 4.https://www.youtube.com/watch?v=kwp9dhooG Rw/ viewed 11 July 2018 . allowed to touch any household pet or livestock. Many young girls, who cannot look after themselves properly, die of exposure in the freezing Himalayas, or of smoke inhalation when trying to stay warm by making a fire in the cabin, or are bitten by snakes that come into the cabin for warmth.

According to the tradition (known as chhaupadi), anyone who contacts a menstruating or impure woman contracts the most deadly diseases; their house might burn down or they may be eaten by wild animals.

It is alarming that despite the fact that millions of women have been menstruating for millions of years, and that menstruation is the basis of fertility and childbearing, there is still the perception of a woman's body as blemished and impure - the 'other' body and the gender that needs to be separated and controlled.

Continually perceived as the 'other' and the outsider, she will remain the eternal stranger, the emotional wanderer in her own house, her own family and her own community. These categories are rooted in cultural or symbolic injustice. There are many layers of oppression and injustice, including cultural domination, non-recognition and disrespect. Marusek (2018:187) suggests that this type of injustice requires recognition that involves the revaluing of identity and the transformation of social patterns of representation that change everybody's sense of self. Cultural feminism argues that the cultural embeddedness of sexist thinking needs to be changed through the ways we support, socialise and erect families and the relationships within the family. A distinct female culture should be fostered, the support rather interdependence than hierarchy in the family, especially the relationship between wife and husband (Gordon 2009).

We need to be critical towards authoritative sacred writings that enforce the subordination and inferiority of women in the family and the community (e.g. 1 Cor 11:13; 14:34). It seems that according to Mark 3:32-35, Jesus (at least) had a different view on family hierarchy. Loader (2005) says:

Jesus' radical sayings about family are more subversive than is usually recognised ... it is a challenge to the household system which underpinned social structure in the ancient world [as a] basis for the systems of control, economy, production and patronage. (p. 142)

\section{Acknowledgements Competing interests}

The author has declared that no competing interests exist.

\section{Author(s) contributions}

I declare that I am the sole author of this research article.

\section{Ethical consideration}

This article followed all ethical standards for a research without direct contact with human or animal subjects. 


\section{Funding information}

This research received no specific grant from any funding agency in the public, commercial or not-for-profit sectors.

\section{Data availability statement}

Data sharing is not applicable to this article as no new data were created or analysed in this study.

\section{Disclaimer}

The views and opinions expressed in this article are those of the author and do not necessary reflect the official policy or position of any affiliated agency of the author.

\section{References}

Ahmed, S., 2000, 'Who knows? Knowing strangers and strangeness', Australian Feminist Studies 15(31), 49-68. https://doi.org/10.1080/713611918

Austin, W.G., 1979, The social psychology of intergroup relations, Brooks/Cole, Monterey CA.

Bauman, Z., 1991, 'A sociological theory of postmodernity', Thesis Eleven 29, 55 viewed 07 July 2018, from https://doi.org/10.1177/072551369102900104

Bauman, Z., 1997, 'The making and unmaking of strangers', in P. Werbner \& T. Modood (eds.), Debating cultural hybridity, pp. 17-136, Zed Books, London.

Bhabha, H.K., 2001, 'The commitment to theory', and 'dissemination'. The location of culture, Routledge, London.

Blenkinsopp, J., 1991, 'The social context of the "outsider woman" in Proverbs 1-9', Biblica 72(4), 457-473.

Brown, P., 1988, The body and society: Men, women and sexual renunciation in early Christianity, Columbia University Press, New York.

Countryman, L.W., 1988, Dirt, greed and sex: Sexual ethics in the New Testament and their implications for today, Fortress Press, Philadelphia, PA.

Dayal, S., 1996, 'Diaspora and double consciousness', The Journal of the Midwest Modern Language Association 29(1), 46-62. https://doi.org/10.2307/1315257

Dreyer, Y., 2005, 'Sexuality and shifting paradigms - Setting the scene', HTS Teologiese Studies / Theological Studies 61(3), 729-751. https://doi.org/10.4102/hts.v61i3.471

Ellemers, N., Spears, R. \& Doosje, B., 1999, Social identity: Context, content and commitment. Blackwell, Oxford.

Esler, P.F., 2000, 'Keeping it in the family: Culture, kinship and identity in 1 Thessalonians and Galatians', in J.W. Van Henten \& A. Brenner (eds.), Families and family relations as represented in early Judaisms and early Christianities: Texts and fictions, pp. 145-184, Deo Publishing, Leiden.

Gordon, C., 2019, Feminist theory explained, viewed 21 July 2019, from https:// owlcation.com/social-sciences/Feminist-Theory.

Hammond, C.E., 1995, 'The demonization of the other: Women and minorities as were tigers', Journal of Chinese Religions 23(1), 59-80. https://doi. org/10.1179/073776995805307211
Instone-Brewer, D., 2002, Divorce and remarriage in the Bible: The social and literary John, Fortress, Minneapolis, MN

Loader, W., 2005, Sexuality and the Jesus tradition, Eerdmans, Grand Rapids, MI.

Malina, B., 1981, The New Testament world: Insights from cultural anthropology, John Knox, Louisville, KY.

Malina, B.J., 1993, The New Testament world: Insights from cultural anthropology, revised edition, Westminster, Louisville, KY.

Malina, B.J., 1996, The social world of Jesus and the Gospels, Routledge, London.

Malina, B.J. \& Rohrbaugh, R.L., 1992, Social-science commentary on the Synoptic Gospels, Fortress Press, Minneapolis, MN.

Marotta, V., 2002, 'Zygmund Bauman: Order, strangerhood and freedom', Thesis Eleven 70, 36-54. https://doi.org/10.1177/0725513602070001005

Marusek, S., 2018, Faith and resistance. The politics of love and war in Lebanon, Pluto Press, London.

McCutcheon, RT. 1999 'Theoretical background: Insides, outsides, and the scholar of Religion', in R.T. McCutcheon (ed.), The insider/outsider problem in the study of Religion: A reader, pp. 64-66, Cassell, London.

Mödler, H., 2018, 'Menstruasie moet g'n taboe saak wees', Beeld, 05 July.

Neusner, J., 1979, The way of Torah: An introduction to Judaism, Duxbury Press, North Scituate, MA.

Nortjé-Meyer, S.J., 2003, 'Die hiërargiese funksionering van God, mans en vroue in die brief aan die Efesiërs', Verbum et Ecclesia 21(1), 180-193. https://doi.org/10.4102/ ve.v24i1.320

Nortjé-Meyer, S.J., 2008, 'Body politics in the letter to the Ephesians', Theologia Viatorum 32(1), 97-113.

Nortjé-Meyer, L. \& Very, A., 2016, 'Artemis as matrix for a new interpretation of the household codes in Ephesians 5:22-6:9', Neotestamentica 50(2), 313-329. https://doi.org/10.1353/neo.2016.0035

Pickering, M., 2001, Stereotyping: The politics of representation, Palgrave, New York.

Rock, J.T., 2017, 'No longer strangers or aliens: "Otherness" as a binding to be loosed in Christian tradition', Journal of Ecumenical Studies 52(1), 113-119. https://doi. org/10.1353/ecu.2017.0015

Simmel, G., 1950, The sociology of George Simmel, transl. K. Wolff, Free Press, New York, viewed 17 June 2019, from www.cardiff.ac.uk/socsi/undergraduate/ introsoc/simmel13.html/.

Tajfel, H., 1969, 'Cognitive aspects of prejudice', Journal of Social Issues 25, 79-97. https://doi.org/10.1111/j.1540-4560.1969.tb00620.x

Tajfel, H., 1978, 'Social categorization, social identity and social comparison', in H. Tajfel (ed.), Differentiation between social groups, pp. 61-76, Academic Press, London.

Tajfel, H., 1981, Human groups and social categories. Studies in social psychology, Cambridge University Press, Cambridge.

Tajfel, H. \& Turner, J.C., 1979, 'An integrative theory of intergroup conflict', in W.G. Austin \& S. Worchel (eds.), The social psychology of intergroup relations, pp. 33-47, Brooks/Coole, Monterey, CA.

Ukwuegbu, B.O., 2008, 'Paranesis, identity-defining norms, or both? Galatians 5:13-6:10 in the light of social identity theory', Catholic Biblical Quarterly 70 538-559.

Van Eck, E., 2007, 'Die huwelik in die eerste-eeuse Mediterreense wêreld (I): Vroue in 'n man se wêreld', HTS Teologiese Studies/Theological Studies 63(1), 81-101. https://doi.org/10.4102/hts.v63i1.204

Vosloo, R., 2004, 'Identity, otherness and the triune God: Theological groundwork for a Christian ethic of hospitality', Journal of Theology for Southern Africa 119, 69-89. 